\title{
Thinking about Accountability
}

\section{Réflexion sur l'obligation de rendre compte}

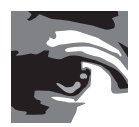

RAISA B. DEBER, PHD

Professor, Institute of Health Policy, Management $E$ Evaluation

University of Toronto

Toronto, ON

\begin{abstract}
Accountability is a key component of healthcare reforms, in Canada and internationally, but there is increasing recognition that one size does not fit all. A more nuanced understanding begins with clarifying what is meant by accountability, including specifying for what, by whom, to whom and how.

These papers arise from a Partnership for Health System Improvement (PHSI), funded by the Canadian Institutes of Health Research (CIHR), on approaches to accountability that examined accountability across multiple healthcare subsectors in Ontario. The partnership features collaboration among an interdisciplinary team, working with senior policy makers, to clarify what is known about best practices to achieve accountability under various circumstances. This paper presents our conceptual framework. It examines potential approaches (policy instruments) and postulates that their outcomes may vary by subsector depending upon (a) the policy goals being pursued, (b) governance/ownership structures and relationships and (c) the types of goods and services being delivered, and their production characteristics (e.g., contestability, measurability and complexity).
\end{abstract}




\section{Résumé}

Lobligation de rendre compte est une composante clé des réformes des services de santé au Canada comme à l'etranger, mais on se rend de plus en plus compte que le même moule ne fonctionne pas pour tous. Il est possible d'en avoir une compréhension plus nuancée en clarifiant sa définition et en précisant ce sur quoi elle doit porter, par qui elle doit être faite, envers qui et comment.

Ces articles sont le fruit d'un partenariat pour l'amélioration du système de santé (PASS), financé par les Instituts de recherche en santé du Canada (IRSC), qui examine les mécanismes de l'obligation de rendre compte dans plusieurs sous-secteurs des services de santé en Ontario. Dans le cadre de ce partenariat, une équipe interdisciplinaire travaille avec des responsables de politiques pour mieux comprendre les pratiques exemplaires de l'obligation de rendre compte dans divers contextes. Cet article présente notre cadre conceptuel. On y examine diverses démarches (instruments de politique) et on présuppose que leurs résultats varient selon les sous-secteurs en fonction (a) des objectifs visés par la politique, (b) des structures et relations de gouvernance/appartenance et (c) du type de biens et services fournis, ainsi que des caractéristiques de leur prestation (par exemple, l'optionnalité, la mesurabilité et la complexité).

\section{ccountability is a key component of many current healthcare reform $\triangle$ efforts, both in Canada and internationally (Canadian Healthcare Association 2001; 1 Leo and Canadian Healthcare Association 2006; Marchildon 2013). But there is} increasing recognition that one size does not fit all, and that it is important to "unpack" the concept and to clarify both what the term accountability means, and which approaches to achieving it might work where. As Brown and colleagues (2006) have noted, "strengthening accountability is central to the recommendations made in all recent studies on the future of health care." Yet there is insufficient information about best practices, and a sense that badly designed or implemented approaches may have unintended negative consequences.

This paper presents the conceptual framework that has guided the research reported in this Special Issue of Healthcare Policy/Politiques de Santé. The research emerged from a Partnership for Health System Improvement (PHSI), funded by the Canadian Institutes of Health Research (CIHR), on approaches to accountability (see also http://www. approachestoaccountability.ca). We use the term "approaches" to refer to the "big picture" that includes such elements as how (the instruments, tools or mechanisms being employed), to whom these elements apply, and the consequences of success or failure. The full project features collaboration among an interdisciplinary team, working in partnership with senior policy makers across multiple healthcare subsectors, to clarify what is known about best practices to achieve accountability under various circumstances. The research design has employed a series of case studies, using a common data collection template, to allow comparison across subsec- 
tors and across jurisdictions, to ascertain the impact of three categories of key independent variables - goals, governance/ownership and services provided - on how accountability is defined and the advantages and disadvantages of the possible approaches.

\section{The Policy Issue}

Accountability has multiple definitions (Mulgan 2000). Most simply, it means having to be answerable to someone, for meeting defined objectives (Emanuel and Emanuel 1996). This can be done in a variety of ways, using a variety of policy instruments. In practice, however, accountability has often proven difficult to achieve, and there are lurking suspicions that approaches suitable under certain circumstances may be suboptimal or counterproductive in other settings. Clarification about the best ways to achieve accountability has been identified as a major priority by governments, providers and recipients of healthcare services, both in Canada and internationally.

The literature suggests that accountability has financial, performance and political/democratic dimensions (Brinkerhoff 2004) and can be ex ante or ex post. Within healthcare, these three dimensions may translate into fiscal accountability to payers, clinical accountability to a variety of actors for quality of care (Dobrow et al. 2008) and accountability to the public. The actors involved may include various combinations of providers (public and private), patients/ service recipients, payers (including insurers and the legislative and executive branches of government) and regulators (governmental, professional) who are connected in various ways (Shortt and Macdonald 2002). The ways to establish and enforce accountability are similarly varied. A more nuanced understanding necessarily begins with clarifying what is meant by accountability, including specifying for what, by whom, to whom and how. A related set of concepts are linked to rewards and punishments, including what happens when outcomes are not achieved. Under those circumstances, being answerable may translate into efforts to censure, shame and blame those who are seen as "accountable" for the failure. In these studies, we concentrate on the potential consequences (both intended and unintended) of using various approaches to ensure that goals are met and performance is being improved.

We accordingly constructed an analytical framework drawing from several literatures that have not previously, to our knowledge, been used to analyze the factors affecting the strengths and weaknesses of various approaches to accountability. Rather than focus on "models" that attempt to force an intrinsically variable concept into boxes, we instead focused on dimensions that might affect performance, policy development or both. One dimension of the framework classified potential approaches to accountability in terms of the political science concept often referred to as "policy instruments" or "governing instruments." We concentrated on four, which were evident in our review of currently used approaches to accountability: financial incentives, regulations, information directed towards patients/payers and professionalism/stewardship which represented variations on the "expenditure," "regulation" and "exhortation" governing instruments. Our framework postulated that these approaches would have differing success when applied to various categories of services, and within various subsectors, with the likely 
outcomes depending upon three additional dimensions: (a) the policy goals being pursued (which affect the question of "accountability for what"); (b) the governance/ownership structures and relationships in place, which in turn affect who will be accountable and to whom; and (c) the types of goods and services being delivered and their "production characteristics." To the extent that different subsectors represented different configurations of governance, ownership and service mix, some of these dimensions will not vary within a particular subsector, while others may vary within and between settings. There is also scope for variation depending on the characteristics of those receiving the services, and their ability to monitor performance. The research reported here thus allowed us to compare and contrast across a series of related substudies.

\section{Approaches: Policy Instruments}

Political scientists have noted that decision-makers have available to them a series of what are termed "policy instruments" or "governing instruments," from which they can select to carry out preferred policy directions (Baxter-Moore 1987; Doern and Phidd 1992; Hood 1983; Howlett and Ramesh 1993).

There are a number of different ways of classifying such instruments. Doern and Phidd (1992) stress increasing government involvement/control, ranging from encouraging cooperation to taking over and directly running the activity; they use the terms exhortation, expenditure, regulation, taxation and public ownership. Another formulation, which makes similar points in slightly different language, is Hood's NATO, which uses the terms nodality (information), authority, treasure and organization (Hood 1983).

These typologies stress that policy instruments vary considerably in how coercive (or intrusive) they are. At the extreme non-intrusive end of the scale, decision-makers may choose not to act at all. Moving slightly up the scale, they can choose symbolic responses to encourage people to act in a particular way. This may involve information/education, symbolic gestures or both. Doern and Phidd (1992) term this approach "exhortation." Somewhat more intrusively, decision-makers may choose to intervene indirectly by using incentives for action, ranging from attempts to secure voluntary compliance with their objectives without accompanying threats or inducements, through to "expenditures" and/or "taxation" policies. A still more intrusive set of instruments may be termed directives (what Doern and Phidd call "regulation"); these often shift compliance costs from regulators to those being regulated. Although most writing on policy instruments conceptualizes coercion as the extent to which government directly intrudes on private decision-making, this analysis can be extended to examining the potential intrusiveness of one level of decision-makers upon others. The framework also includes the literature on ways of enforcing these agreements, including information, licensure/accreditation, payment and legal sanctions. This literature has been linked to the literature on the new public management (Hood 2000) and pays particular attention to interactions between public and private forces, as well as the implications of the type of policy network for selection of policy instrument (Bressers and O'Toole 1998). Although these 
concepts have been applied to the field of environmental regulation, particularly in the European Union (Jordan et al. 2005; Zito et al. 2003) as well as, in a more limited way, to healthcare - e.g., the governance of primary care in Switzerland (Braun and Etienne 2004) and social services, such as child health policy in Australia (Leggat 2004) - we are not aware of any efforts to apply them to accountability.

In these studies, we have focused on the following four major approaches to accountability currently being employed in the health sector in Canada and internationally:

1. Financial incentives, which adjust payments to induce providers to behave in a desired manner (Donaldson et al. 2005; Evans 1984; Robinson 2001). These employ the "expenditure" governing instrument (also called "treasure"). One example is the family of pay-forperformance (P4P) experiments for physician services underway in such jurisdictions as the United Kingdom, United States, Australia and Ontario (Devlin et al. 2006; Doran et al. 2006; Epstein 2006; Pink et al. 2006; Rosenthal et al. 2005), which often tie funds to performance of desired activities (Marks et al. 2011). Another involves changes in the financial incentives for hospitals, including moves to activity-based funding (Chalkley and Malcomson 2000; Sutherland 2011; Sutherland et al. 2011). Similar initiatives can be found in other subsectors, including home care.

2. Regulations, which by definition employ the "regulation" governing instrument (Walshe 2003), play a major role in healthcare. These require providers to behave (or not behave) in a certain way. Although regulations can be backed up through signing binding agreements, they may also rely on agency theory (Eisenhardt 1989; McGuire 2000) and be enforced using professional regulatory bodies. The literature notes the ongoing tension of balancing market forces and regulation (Chinitz et al. 1998; Saltman et al. 2002) and the implications of regulatory and medico-legal barriers for achieving such goals as interprofessional practice (Lahey and Currie 2005).

3. Information directed towards potential users (patients, public and private payers) within a context of allowing market forces to work more effectively by encouraging rational choice of the "best" care (Howells 2005). These are one variant of the "exhortation" governing instrument. This instrument may work both directly and indirectly (e.g., interest groups and media may affect the reputation of various providers, which in turn affects the willingness of patients and payers to purchase their services). Examples of the use of information include ongoing activities in performance measurement and improvement (Barnsley et al. 2005; Hurst and Jee-Hughes 2001; Shaw 2003; Smith 2002; Veillard et al. 2005). Issues in using this approach include who establishes these measures and who enforces them. In healthcare, common examples include the use of report cards (e.g., for hospitals), audit reports, publicly available inspection reports (e.g., for nursing homes) and quality indicators, including adverse events (Baker et al. 2004). The Health Council of Canada and the Canadian Institute for Health Information have been involved in developing, collecting and publicizing various informational mechanisms. 
4. Reliance on professionalism and stewardship (Saltman and Ferroussier-Davis 2000; Shortell et al. 1998). This approach employs a second variant of the exhortation governing instrument, but directs the information to providers rather than to payers or consumers (Lemieux-Charles and Champagne 2004). It relies on high trust and the expectation that providers - as a group - wish to do the right thing, but may need support in clarifying best practices as well as exposing poor practice. Clinical guidelines and other forms of evidence-based practice often fall within this category if compliance is voluntary; they are currently being used in various subsectors, including hospitals, nursing homes and primary healthcare. Under some circumstances, report cards may also fall into this category of approach, depending upon the indicators used and the dissemination approach adopted. Note that this approach is often backed up by regulatory approaches (e.g., through selfregulation of the professions).

An additional nuance is the extent to which blended models may be used. This is particularly evident in the use of additional policy instruments for enforcement, which may include various combinations of information (e.g., efforts to evaluate and improve the quality of information, citizen engagement to widen the scope of inputs) (Abelson and Guavin 2004), expenditure (e.g., fiscal penalties), taxation (e.g., tax breaks to encourage desired activities) and regulation (e.g., audit, accreditation, professional self-regulation and legal sanctions). Some jurisdictions have established formal appeal mechanisms for patients (e.g., Norway has a Patient's Bill of Rights; Ontario has the various review procedures for getting out-of-province coverage and a public complaints process for nursing homes). Other enforcement mechanisms may rely upon litigation (e.g., malpractice, human rights). Auditor General reports fall within the information category, but may often catalyze additional actions.

\section{What Affects the Impact of Accountability Approaches?}

The second component of this framework focuses on three dimensions likely to affect the success of various approaches: goals, governance/ownership and services.

Policy goals may encompass both outcomes and processes. Policy goals for healthcare traditionally include combinations of access, quality (including safety), cost control/cost-effectiveness and customer satisfaction. Behn (2001) suggests three objectives for accountability: improved performance, fairness and financial stewardship. Often, policy goals may clash. For example, hospital effectiveness may vary if measured in terms of doing more (increasing the number of admissions, market share, occupancy rate), financial performance (net profit, cash flow), meeting the needs of the community (satisfaction of patients, providers) or delivering high-quality care (better outcomes). Ideally, there should be congruence between the policy goals being pursued and what organizations are being held accountable for, although this is not always the case.

The governance/ownership structures in place also vary across jurisdictions and across subsectors; they affect who will be accountable, to whom and for what (Denis 2004; Jordan 
et al. 2005; van Kersbergen and van Waarden 2004). One key element is the balance between and rationale for public versus private provision and how such factors affect governance and accountability (Deber 2004; Horwitz 2006; Osborne and Gaebler 1992; Sloan 2000). For example, for-profit organizations also have a fiduciary duty to maximize the return to their investors, which in turn may affect the services they choose to provide and the populations they choose to serve.

As Denis and colleagues (2005) have noted, "governance deals principally with the adaptation of organizations to new contingencies" and deals with "the roles of all regulatory, administrative, professional and clinical authorities in the pursuit of collective goals." In that connection, structures where actors are accountable to more than one authority can add complexity (Rhodes 1997). An additional complexity is that Canada is what the Organisation for Economic Co-operation and Development (OECD) refers to as a "public-contract model," in which public payers contract with private healthcare providers (Docteur and Oxley 2003). In turn, this means that many accountability arrangements are between government and the "third sector" ("civil society"), a situation that presents additional complications (Mayne and Wilkins 2005; Schwartz 2001, 2002, 2003).

Ownership presents further issues; one US study found that the effects of the governance/ownership configuration were more pronounced in freestanding and public not-for-profit hospitals compared with system-affiliated and private not-for-profit hospitals. The board structure, including whether corporate-style or philanthropic-style models were used, was also important (Alexander and Lee 2006). Some have suggested that this governance/ownership category of variables may be the most amenable to policy change (Preker and Harding 2003). One potentially useful concept is the "soft governance" approach, in which government "relies less on hierarchy than on information to steer local organizations" (Brandsen et al. 2006). There is literature suggesting a relationship between governance/ownership and the ability to achieve and monitor such goals as quality improvement (Baker et al. 2006; Thomas 2006). A helpful resource is the framework developed by Denis and colleagues (2005) for Accreditation Canada, which identifies three governance models (agency, stakeholder and stewardship).

We also postulate that what economists call the production characteristics of the goods and services being delivered - specifically, what the literature refers to as contestability, measurability and complexity - will affect performance measurement and monitoring (Deber 2004; Jakab et al. 2002; Preker and Harding 2000, 2003; Preker et al. 2000; Rico and Puig-Junoy 2002; Vining and Globerman 1999). Preker and Harding (2000) define them as follows: "Contestable goods are characterized by low barriers to entry and exit from the market, whereas non-contestable goods have high barriers such as sunk cost, monopoly market power, geographic advantages and asset specificity." These authors define measurability as relating to "the precision with which inputs, processes, outputs and outcomes of a good or service can be measured." Monitoring performance is easiest when measurability is high. For example, it is relatively simple to specify the performance desired for conducting a laboratory test or collecting municipal garbage. In contrast, it would be more difficult to specify the activities to be 
expected of a general practitioner, and hence more difficult to monitor the physician's performance and ensure quality. Complexity refers not to how complex the particular goods and services are, but to whether the goods and services stand alone or require coordination with other providers. For example, laboratory tests are highly measurable, but gain much of their value by being embedded within a system of care in which providers order tests appropriately and are aided in interpreting and acting upon their results. A related concept that emerged from our research is observability, which we define as the extent to which the activities are easily monitored by others beyond those directly involved in providing or receiving a service. For example, services delivered in a home setting would be less observable than those delivered in a hospital operating room. Additional insights arise from the theory of transaction costs and monitoring costs, which are also addressed in economics theories relating to incomplete contracting (Williamson 1981, 1985, 1999), defined by Williamson (1985) as "the comparative costs of planning, adapting and monitoring task completion under alternative governance structures."

\section{Substudies and Decision-Making Partners}

The substudies examined in this Special Issue encompass a variety of subsectors, including hospitals (Kraetschmer et al. 2014; Kromm et al. 2014), cancer (Bytautas et al. 2014), community services (Steele Gray et al. 2014), laboratories (Gamble et al. 2014), public health (Schwartz et al. 2014), primary healthcare (Mukhi et al. 2014), long-term care (Berta et al. 2014; Wyers et al. 2014) and professional regulation (Baumann et al. 2014; Zelisko et al. 2014), and brief commentaries looking at international comparisons (Kirsch 2014; Peckham 2014) and the role of accreditation (Mitchell et al. 2014). These substudies represent different combinations of governance/ownership and services, and should assist in clarifying the advantages and disadvantages of various approaches to accountability. We are extremely fortunate to have the collaboration of such highly qualified decision-making partners and researchers (including graduate students).

The final paper of this Special Issue (Deber 2014) summarizes what we have learned from the substudies.

\section{Acknowledgements}

This study was funded by CIHR-PHSI Grant (CIHR Grant Number PHE-101967).

We thank our team members for helpful comments, particularly Andrea Baumann, Tony Culyer, Nancy Kraetschmer, Heather Manson, Patricia Norman and Valerie Rackow.

We thank our decision-making partners: Accreditation Canada; Association of Canadian Academic Healthcare Organizations; Association of Ontario Health Centres; Canadian Healthcare Association; Canadian Home Care Association; Canadian Medical Association; Cancer Care Ontario; City of Toronto, Long-Term Care Homes and Services; College of Physicians and Surgeons of Canada; College of Nurses of Ontario; Council of Academic Hospitals of Ontario; Fasken Martineau; Mississauga Halton Local Health Integration Network; Ontario Association of Non-Profit Homes and Services for Seniors; Ontario 
College of Family Physicians; Ontario Community Support Association; Ontario Hospital Association; Ontario Long-Term Care Association; Ontario Medical Association; Ontario Ministry of Health and Long-Term Care; Ontario Ministry of Health and Long-Term Care Ontario Internal Audit Branch; Ontario Ministry of Health and Long-Term Care - Public Health Practice Branch; Peel Region Medical Officer of Health; Public Health Ontario; Quality Management Program - Laboratory Services; Toronto Central Community Care Access Centre; Toronto Central Local Health Integration Network; VON Canada; William Osler Health System.

Correspondence may be directed to: Raisa B. Deber, PhD, Professor, Institute of Health Policy, Management E Evaluation, 155 College St., Suite 425, Toronto, ON M5T 3M6; tel.: 416-9788366; fax: 416-978-7350; e-mail: raisa.deber@utoronto.ca.

\section{References}

Abelson, J. and F.-P. Guavin. 2004 (April).“Engaging Citizens: One Route to Health Care Accountability." Health Care Accountability Papers, No. 2. Ottawa: Canadian Policy Research Networks. Retrieved March 15, 2014. $<$ http://rcrpp.ca/documents/28104_en.pdf $>$.

Alexander, J.A. and S.-Y.D. Lee. 2006. “Does Governance Matter? Board Configuration and Performance in Notfor-Profit Hospitals." Milbank Quarterly 84(4): 733-58. doi: 10.1111/j.1468-0009.2006.00466.x.

Baker, G.R., P.G. Norton, V. Flintoft, R. Blais, A.D. Brown, J. Cox et al. 2004.“The Canadian Adverse Events Study: The Incidence of Adverse Events among Hospital Patients in Canada." Canadian Medical Association Journal 170(11): 1678-86. doi: 10.1503/cmaj.1040498.

Baker, G.R., P.G. Norton and J.P. Gardner 2006. Contribution of Governance to Patient Safety Initiatives in Australia, England, New Zealand and the United States. Ottawa: Health Canada. Retrieved March 16, 2014. <http://books. google.ca/books/about/Contribution_of_Governance_to_Patient_Sa.html?id=bytEtwAACAAJ\&redir_esc=y > . Barnsley, J., W. Berta, R. Cockerill, J. MacPhail and E. Vayda. 2005. “Identifying Performance Indicators for Family Practice: Assessing Levels of Consensus." Canadian Family Physician 51(5): 700-01.

Baumann, A., P. Norman, J. Blythe, S. Kratina and R.B. Deber. 2014. "Accountability: The Challenge for Medical and Nursing Regulators." Healthcare Policy 10(Special Issue): 121-31.

Baxter-Moore, N. 1987."Policy Implementation and the Role of the State: A Revised Approach to the Study of Policy Instruments." In R.J. Jackson, D. Jackson and N. Baxter-Moore, eds., Contemporary Canadian Politics: Reading and Notes (pp. 336-55). Toronto: Prentice-Hall Canada.

Behn, R. 2001. Rethinking Democratic Accountability. Washington, DC: Brookings Institution Press.

Berta, W., A. Laporte and W.P. Wodchis. 2014. "Approaches to Accountability in Long-Term Care." Healthcare Policy 10(Special Issue): 132-44.

Brandsen, T., M. Boogers and P. Tops. 2006. "Soft Governance, Hard Consequences: The Ambiguous Status of Unofficial Guidelines." Public Administration Review 66(4): 546-53. doi: 10.1111/j.1540-6210.2006.00615.x.

Braun, D. and J. Etienne. 2004. Policy Ideas and Health Policy Instruments: The Governance of Primary Care in Switzerland. Lausanne, Switzerland: Université de Lausanne. Retrieved March 16, 2014. <http://www.unil.ch/ files/live//sites/iepi/files/users/epibiri1/public/HealthPolicyMix.pdf>.

Bressers, H.T.A. and L. J. O’Toole. 1998. “The Selection of Policy Instruments: A Network-Based Perspective.” Journal of Public Policy 18(3): 213-39.

Brinkerhoff, D.W. 2004. "Accountability and Health Systems: Toward Conceptual Clarity and Policy Relevance." Health Policy and Planning 19(6): 371-79. doi: 10.1093/heapol/czh052.

Brown, A.D., C. Porcellato and J. Barnsley. 2006. “Accountability: Unpacking the Suitcase." Healthcare Quarterly 9(3): 72-75. doi: $10.12927 /$ hcq. 18231. 
Bytautas, J., M. Dobrow, T. Sullivan and A. Brown. 2014. "Accountability in the Ontario Cancer Services System: A Qualitative Study of System Leaders' Perspectives." Healthcare Policy 10(Special Issue): 45-55.

Canadian Healthcare Association. 2001. Towards Improved Accountability in the Health System: Getting from Here to There. Ottawa: Author.

Chalkley, M. and J.M. Malcomson. 2000. “Government Purchasing of Health Services." In A.J. Culyer and J.P. Newhouse, eds., Handbook of Health Economics (vol. 1, part A) (pp. 847-90). Amsterdam: Elsevier.

Chinitz, D., A. Preker and J.R. Wasem. 1998. "Balancing Competition and Solidarity in Health Care Financing." In R.B. Saltman, J. Figueras and C. Sakellarides, eds., Critical Challenges for Health Care Reform in Europe (pp. 55-77). Buckingham: Open University Press.

Deber, R.B. 2004. “Delivering Health Care Services: Public, Not-for-Profit, or Private?” In G.P. Marchildon, T. McIntosh and P.-G. Forest, eds., The Fiscal Sustainability of Health Care in Canada (Romanow Papers, vol. 1) (pp. 233-96). Toronto: University of Toronto Press.

Deber, R.B. 2014. “What Have We Learned from the Substudies?” Healthcare Policy 10(Special Issue): $163-64$.

Denis, J.-L. 2004. “Governance and Management of Change in Canada's Health System." In P.-G. Forest, G.P. Marchildon and T. McIntosh, eds., Changing Health Care in Canada (Romanow Papers, vol. 2) (pp. 82-114).

Toronto: University of Toronto Press.

Denis J.L., F. Champagne, M.P. Pomey, J. Préval and G. Tré 2005. Towards a Framework for the Analysis of Governance in Health Care Organizations. Preliminary Report Presented to the Canadian Council on Health Services Accreditation, October 2005, Université de Montréal.

Devlin, R.A., S. Sarma and W. Hogg. 2006. "Remunerating Primary Care Physicians: Emerging Directions and Policy Options for Canada." Healthcare Quarterly 9(3): 34-42. doi: 10.12927/hcq.18225.

Dobrow, M.J., T. Sullivan and C. Sawka. 2008. "Shifting Clinical Accountability and the Pursuit of Quality: Aligning Clinical and Administrative Approaches." Healthcare Management Forum 21(3): 6-12. doi: 10.1016/ S0840-4704(10)60269-4.

Docteur, E. and H. Oxley. 2003. Health-Care Systems: Lessons from the Reform Experience. Paris: OECD Publishing. Retrieved March 16, 2014. <http://www.oecd.org/health/health-systems/22364122.pdf>.

Doern, G.B. and R.W. Phidd. 1992. Canadian Public Policy: Ideas, Structure, Process (2nd ed.). Toronto: Nelson Canada.

Donaldson, C., K. Gerard, S. Jan, C. Mitton and V. Wiseman. 2005. Economics of Health Care Financing: The Visible Hand (2nd ed.). Basingstoke, UK: Palgrave/Macmillan.

Doran, T., C. Fullwood, H. Gravelle, D. Reeves, E. Kontopantelis, U. Hiroeh et al. 2006. "Pay-for-Performance Programs in Family Practices in the United Kingdom." New England Journal of Medicine 355(4): 375-84. doi: 10.1056/NEJMsa055505.

Eisenhardt, K.M. 1989. "Agency Theory: An Assessment and Review." Academy of Management Review 14(1): 57-74. doi: 10.5465/AMR.1989.4279003.

Emanuel, E.J. and L.L. Emanuel. 1996. "What Is Accountability in Health Care?" Annals of Internal Medicine 124(2): 229-39. doi: 10.7326/0003-4819-124-2-199601150-00007.

Epstein, A.M. 2006. "Paying for Performance in the United States and Abroad." New England Journal of Medicine 355(4): 406-8, doi: 10.1056/NEJMe068131.

Evans, R.G. 1984. Strained Mercy: The Economics of Canadian Health Care. Toronto: Butterworths.

Gamble, B., L. Bourne and R.B. Deber 2014. "Accountability through Regulation in Ontario's Medical Laboratory Sector." Healthcare Policy 10(Special Issue): 67-78.

Hood, C.C. 1983. The Tools of Government. Chatham, NJ: Chatham House Publishers.

Hood, C. 2000. "Paradoxes of Public-Sector Managerialism, Old Public Management and Public Service Bargains." International Public Management Journal 3(1): 1-22. doi: 10.1016/S1096-7494(00)00032-5.

Horwitz, J. 2006. “Nonprofit Ownership, Private Property and Public Accountability”. Health Affairs 25(4): w30811. doi: $10.1377 /$ hlthaff.25.w308.

Howells, G. 2005. “The Potential and Limits of Consumer Empowerment by Information.” Journal of Law and Society 32(3): 349-70. doi: 10.1111/j.1467-6478.2005.00328.x. 
Howlett, M. and M. Ramesh. 1993. "Patterns of Policy Instrument Choice: Policy Styles, Policy Learning and the Privatization Experience." Policy Studies Review 12(1-2): 3-24. doi: 10.1111/j.1541-1338.1993.tb00505.x.

Hurst, J. and M. Jee-Hughes. 2001. Performance Measurement and Performance Management in OECD Health Systems. Paris: Organisation for Economic Co-operation and Development. Retrieved March 16, 2014. <http:// www.oecd-ilibrary.org/social-issues-migration-health/performance-measurement-and-performance-managementin-oecd-health-systems_788224073713>.

Jakab, M., A. Preker, A. Harding and L. Hawkins. 2002. The Introduction of Market Forces in the Public Hospital Sector: From New Public Sector Management to Organizational Reform. Washington, DC: World Bank's Human Development Network, Health, Nutrition, and Population. Retrieved March 16, 2014. <http://siteresources. worldbank.org/HEALTHNUTRITIONANDPOPULATION/Resources/281627-1095698140167/JakabTheIntroductionof-whole.pdf $>$.

Jordan, A., R.K.W. Wurzel and A. Zito. 2005.“The Rise of 'New' Policy Instruments in Comparative Perspective: Has Governance Eclipsed Government?" Political Studies 53(3): 477-96. doi: 10.1111/j.1467-9248.2005.00540.x.

Kirsch, D. 2014."How Do the Approaches to Accountability Compare for Charities Working in International Development?" Healthcare Policy 10(Special Issue): 145-49.

Kraetschmer, N., J. Jass, C. Woodman, I. Koo, S.K. Kromm and R.B. Deber. 2014. “Hospitals' Internal Accountability.” Healthcare Policy 10(Special Issue): 36-44.

Kromm, S.K., G.R. Baker, W.P. Wodchis and R.B. Deber. 2014. “Acute Care Hospitals' Accountability to Provincial Funders." Healthcare Policy 10(Special Issue): 25-35.

Lahey, W. and R. Currie. 2005. "Regulatory and Medico-Legal Barriers to Interprofessional Practice." Journal of Interprofessional Care 19(S1): 197-223. doi: 10.1080/13561820500083188.

Leggat, S.G. 2004. "Healthy Children, Healthy Country: The Use of Governing Instruments in Shifting the Policy Paradigm." Australia and New Zealand Health Policy 1(4): 1-4. doi: 10.1186/1743-8462-1-4.

Lemieux-Charles, L. and F. Champagne, eds. 2004. Using Knowledge and Evidence in Health Care: Multidisciplinary Perspectives. Toronto: University of Toronto Press.

Leo, A. and Canadian Healthcare Association. 2006. Achieving Health System Excellence in Canada - Working in Partnerships to Implement Principles for Governance, Management, Accountability and Shared Responsibility: Summary Report of the Canadian Healthcare Association's National Roundtable on Health System Effectiveness, December 15-16, 2005, Ottawa, ON. Ottawa: Canadian Health Care Association.

Marchildon, G.P. 2013. Canada: Health System Review (vol. 15). Copenhagen: European Observatory on Health Systems and Policies. Retrieved March 24, 2014. <http://www.euro.who.int/_data/assets/pdf_ file/0011/181955/e96759.pdf>.

Marks, L., S. Cave, A. Wallace, A. Mason, D. J. Hunter, J. M. Mason et al. 2011.“Incentivizing Preventive Services in Primary Care: Perspectives on Local Enhanced Services." Journal of Public Health 33(4): 556-64. doi: 10.1093/ pubmed/fdr016.

Mayne, J. and P. Wilkins. 2005. “Believe It or Not: The Emergence of Performance Information Auditing." In R. Schwartz and J. Mayne, eds., Quality Matters: Seeking Confidence in Evaluation, Auditing and Performance Reporting (pp. 237-60). New Brunswick, NJ: Transaction Publishers.

McGuire, T.G. 2000. “Physician Agency." In A.J. Culyer and J.P. Newhouse, eds., Handbook of Health Economics (vol. 1, part A) (5th ed., pp. 461-536). Amsterdam: Elsevier.

Mitchell, J.I., W. Nicklin and B. MacDonald. 2014."The Accreditation Canada Program: A Complementary Tool to Promote Accountability in Canadian Healthcare." Healthcare Policy 10(Special Issue): 150-53.

Mukhi, S., J. Barnsley and R.B. Deber. 2014. “Accountability and Primary Healthcare." Healthcare Policy 10(Special Issue): $90-98$.

Mulgan, R. 2000. "Accountability': An Ever-Expanding Concept?" Public Administration 78(3): 555-73. doi: 10.1111/1467-9299.00218.

Osborne, D.E. and T. Gaebler. 1992. Reinventing Government: How the Entrepreneurial Spirit Is Transforming the Public Sector. Reading, MA: Addison-Wesley.

Peckham, S. 2014. “Accountability in the UK Healthcare System: An Overview." Healthcare Policy 10(Special Issue): 154-62. 
Pink, G.H., A.D. Brown, M.L. Studer, K.L. Reiter and P. Leatt. 2006. "Pay-for-Performance in Publicly Financed Healthcare: Some International Experience and Considerations for Canada" Healthcare Papers 6(4): 8-26. doi: 10.12927/hcpap.2006.18260.

Preker, A.S. and A. Harding. 2000. The Economics of Public and Private Roles in Health Care: Insights from Institutional Economics and Organizational Theory. Washington, DC: The International Bank for Reconstruction and Development/The World Bank. Retrieved March 16, 2014. <http://siteresources.worldbank.org/HEALTHNUTRITIONANDPOPULATION/Resources/281627-1095698140167/PrekerTheEconomicsOfPublic-whole.pdf>.

Preker, A.S. and A. Harding, eds. 2003. Innovations in Health Service Delivery: The Corporatization of Public Hospitals. Washington, DC: The World Bank.

Preker, A.S., A. Harding and P. Travis. 2000. 'Make or Buy' Decisions in the Production of Health Care Goods and Services: New Insights from Institutional Economics and Organizational Theory. Bulletin of the World Health Organization 78(6): 779-89. doi: 10.1590/S0042-96862000000600010. <http://www-wds.worldbank.org/ external/default/WDSContentServer/WDSP/IB/2001/03/26/000094946_0103200658248/Rendered/PDF/ multi0page.pdf $>$.

Rhodes, R.A.W. 1997. Understanding Governance: Policy Networks, Governance, Reflexivity and Accountability. Buckingham, UK: Open University Press.

Rico, A. and J. Puig-Junoy. 2002. “What Can We Learn from the Regulation of Public Utilities?” In R.B. Saltman, R. Busse and E. Mossialos, eds., Regulating Entrepreneurial Behaviour in European Health Care Systems (pp. 73-90). Buckingham, UK: Open University Press.

Robinson, J.C. 2001. “Theory and Practice in the Design of Physician Payment Incentives." Milbank Quarterly 79(2): 149-77. doi: 10.1111/1468-0009.00202.

Rosenthal, M.B., R.G. Frank, Z. Li and A.M. Epstein. 2005. “Early Experience with Pay-for-Performance: From Concept to Practice." Journal of the American Medical Association 294(14): 1788-93. doi: 10.1001/ jama.294.14.1788.

Saltman, R.B., R. Busse and E. Mossialos, eds. 2002. Regulating Entrepreneurial Behaviour in European Healthcare Systems. Buckingham, UK: Open University Press.

Saltman, R.B. and O. Ferroussier-Davis. 2000. "The Concept of Stewardship in Health Policy." Bulletin of the World Health Organization 78(6): 732-39. doi: 10.1590/S0042-96862000000600005.

Schwartz, R. 2001. "Managing Government - Third Sector Collaboration: Accountability, Ambiguity and Politics." International Journal of Public Administration 24(11): 1161-88. doi: 10.1081/PAD-100105234.

Schwartz, R. 2002. “Accountability in New Public Management: An Elusive Phenomenon?” In E. Vigoda-Gadot, ed., Public Administration: An Interdisciplinary Critical Analysis (pp. 63-84). New York: Marcel Dekker.

Schwartz, R. 2003. “The Politics of Evaluating Government Collaboration with the Third Sector." In A. Gray, B. Jenkins, F. Leeuw and J. Mayne, eds., Collaboration in Public Services: The Challenge for Evaluation (pp. 83-104). New Brunswick, NJ: Transaction Publishers.

Schwartz, R., A. Price, R.B. Deber, H. Manson and F. Scott. 2014. "Hopes and Realities of Public Health Accountability Policies." Healthcare Policy 10(Special Issue): 79-89.

Shaw, C. 2003. How Can Hospital Performance Be Measured and Monitored? Copenhagen, WHO Regional Office for Europe. Retrieved March 16, 2014. <http://www.euro.who.int/_data/assets/pdf_file/0009/74718/E82975. pdf $>$.

Shortell, S.M., T.M. Waters, K.W.B. Clarke and P.P. Budetti. 1998. "Physicians as Double Agents: Maintaining Trust in an Era of Multiple Accountabilities." Journal of the American Medical Association 280(12): 1102-08. doi: 10.1001/jama.280.12.1102.

Shortt, S.E.D. and J.K. Macdonald. 2002. "Toward an Accountability Framework for Canadian Healthcare." Healthcare Management Forum 15(4): 24-32.

Sloan, F.A. 2000. "Not-for-Profit Ownership and Hospital Behavior." In A.J. Culyer and J.P. Newhouse, eds., Handbook of Health Economics (5th ed., vol. 1, part B) (pp. 1141-74). Amsterdam: Elsevier.

Smith, P., ed. 2002. Measuring Up: Improving Health System Performance in OECD Countries. Paris: Organisation for Economic Co-operation and Development. 
Steele Gray, C., W. Berta, R.B. Deber and J. Lum. 2014. “Home and Community Care Sector Accountability." Healthcare Policy 10(Special Issue): 56-66.

Sutherland, J.M. 2011. Hospital Payment Mechanisms: An Overview and Options for Canada. CHSRF Series of Reports on Cost Drivers and Health System Efficiency: Paper 4. Ottawa: Canadian Health Services Research Foundation. Retrieved March 16, 2014. <http://www.cfhi-fcass.ca/Libraries/Hospital_Funding_docs/CHSRFSutherland-HospitalFundingENG.sflb.ashx $>$.

Sutherland, J.M., M.L. Barer, R.G. Evans and R.T. Crump. 2011. “Will Paying the Piper Change the Tune?" Healthcare Policy 6(4): 14-21. doi: 10.12927/hcpol.2011.22391.

Thomas, P.G. 2006. "From Good Intentions to Successful Implementation: The Case of Patient Safety in Canada." Canadian Public Administration 49(4): 415-41. doi: 10.1111/j.1754-7121.2006.tb01992.x.

van Kersbergen, K. and F. van Waarden. 2004."'Governance' as a Bridge between Disciplines: Cross-Disciplinary Inspiration Regarding Shifts in Governance and Problems of Governability, Accountability and Legitimacy." European Journal of Political Research 43(2): 143-71. doi: 10.1111/j.1475-6765.2004.00149.x.

Veillard, J., F. Champagne, N. Klazinga, V. Kazandjian, O.A. Arah and A. L. Guisset. 2005. “A Performance Assessment Framework for Hospitals: The WHO Regional Office for Europe Path Project." International Journal for Quality in Health Care 17(6): 487-96. doi: 10.1093/intqhe/mzi072.

Vining, A.R. and S. Globerman. 1999. “Contracting Out Health Care Services: A Conceptual Framework." Health Policy 46(2): 77-96. doi: 10.1016/S0168-8510(98)00056-6.

Walshe, K. 2003. Regulating Healthcare: A Prescription for Improvement? Maidenhead, UK: Open University Press. Williamson, O.E. 1981. “The Economics of Organization: The Transaction Cost Approach.” American Journal of Sociology 87(3): 548-77.

Williamson, O.E. 1985. The Economic Institutions of Capitalism. New York: The Free Press.

Williamson, O.E. 1999. "Public and Private Bureaucracies: A Transaction Cost Economics Perspective." Journal of Law, Economics \& Organization 15(1): 306-42. doi: 10.1093/jleo/15.1.306.

Wyers, L., B. Gamble and R.B. Deber. 2014. "Accountability in the City of Toronto's 10 Long-Term Care Homes." Healthcare Policy 10(Special Issue): 99-109.

Zelisko, D., A. Baumann, B. Gamble, A. Laporte and R.B. Deber. 2014."Ensuring Accountability through Health Professional Regulatory Bodies: The Case of Conflict of Interest." Healthcare Policy 10(Special Issue): $110-20$.

Zito, A.R., C.M. Radaelli and A. Jordan. 2003. “Introduction to the Symposium on 'New' Policy Instruments in the European Union." Public Administration 81(3): 509-11. doi: 10.1111/1467-9299.00358. 